\title{
Capital Theory, Crises, and Business Cycles: The Triangular Debate between Hayek, Keynes, and Sraffa
}

\author{
Heinz D. Kurz*
}

The Graz Schumpeter Centre, University of Graz, Graz, Austria

\begin{abstract}
The paper discusses aspects of the triangular debate between Hayek, Keynes, and Sraffa on economic crises, business cycles and the role of capital theory in an analysis of these phenomena. It is argued that Sraffa was both critical of Hayek's monetary overinvestment theory and Keynes's use of the concept of commodity rates of interest Sraffa had employed in his criticism of Hayek and of Keynes's theory of liquidity preference.
\end{abstract}

Keywords: Business cycles, Capital theory, Crises, F.A. von Hayek, J.M. Keynes, P. Sraffa.

\section{INTRODUCTION}

Invited by Lionel Robbins to give a set of lectures at the London School of Economics (LSE) and to write a review essay of Keynes's Treatise on Money (Keynes 1930; see CW, Volumes $\mathrm{V}$ and $\mathrm{VI}$ ) for Economica, the journal of the LSE, Friedrich August Hayek in the 1930s assumed the role of a main adversary of Keynes's explanation of unemployment and economic crises in terms of a lack of aggregate effective demand (Hayek, 1931a, 1932a). Hayek advocated an "Austrian" version of orthodox theory, building upon the works of Ludwig von Mises, Eugen von Böhm-Bawerk and Vilfredo Pareto. When Sraffa was confronted with Hayek's argument he knew already that its theoretical core - Böhm-Bawerk's theory of capital and interest was shaky. Therefore, he must have been amused, when in his rejoinder to Keynes's reply to his criticism of The Treatise Hayek maintained that the main weakness of Keynes's argument was its lack of a proper capital theoretic foundation and that he, Keynes, was well advised to adopt Böhm-Bawerk's theory (Hayek, 1931b). While Sraffa certainly saw the need for such a foundation, he knew that Böhm-Bawerk had failed to offer one that is sustainable.

Keynes appears to have accepted the first part of Hayek's criticism and was on the lookout for such a foundation on which he could erect his new edifice, The General Theory (Keynes 1936; see CW, Vol. VII). He was not willing to follow Hayek's advice, because in all probability Sraffa had told him that Böhm-Bawerk's theory was deficient and therefore could not serve the purpose at hand. Was there another option available? Keynes appears to have convinced himself that there was indeed such an option and that it consisted of

*Address correspondence to this author at The Graz Schumpeter Centre, University of Graz, Graz, Austria; Tel: +43-316-380 3444;

Fax: +43-316-380 3590; E-mail: heinz.kurz@uni-graz.at
Sraffa's concept of commodity rate of interest. This concept Sraffa had put forward in his criticism of Hayek (see Sraffa 1932a). There is no evidence that Sraffa himself made Keynes think this way or talked to him about it. On the contrary, there is every reason to believe that Sraffa, had he been confronted with Keynes's intention at an early time, he would have advised Keynes against using the concept in order to put his analysis on a solid capital theoretic basis. In Sraffa (1932a) the concept served a purely critical purpose. Since I have dealt with the debate between Hayek and Sraffa in some detail elsewhere (see Kurz 2000), here I focus attention exclusively on Sraffa's use of the concept of commodity (or "own) rates of interest in his criticism of Hayek in Section 2 and Sraffa's criticism of the particular use Keynes made of the concept in Section 3. Section 4 concludes.

\section{SRAFFA'S CRITICISM OF HAYEK}

Keynes had difficulties to counter Hayek's attack on The Treatise because like other Anglo-Saxon and American economists he did not know the main building blocks of Hayek's analysis: the theories of Mises, Böhm-Bawerk and Pareto. It was therefore natural for Keynes to ask Sraffa, who read German and, of course, Italian, and who, Keynes knew, was familiar with the three intellectual traditions to help him out of the impasse and ward off Hayek's attack.

This Sraffa succeeded in doing. Among other things, he took issue with Hayek's claim that a difference between the actual or money rate of interest and the "natural" or "equilibrium rate" is a characteristic feature of a money economy (Sraffa 1932a: 49). With reference to Knut Wicksell's definition (Wicksell 1898: 93 et seq.) that interest is the surplus in real units of the exchange of physically homogeneous goods across time he emphasized: 
If money did not exist, and loans were made in terms of all sorts of commodities, there would be a single rate which satisfies the conditions of equilibrium, but there might be at any moment as many "natural" rates of interest as there are commodities, though they would not be "equilibrium" rates. The "arbitrary" action of the banks is by no means a necessary condition for the divergence; if loans were made in wheat and farmers (or for that matter the weather) "arbitrarily changed" the quantity of wheat produced, the actual rate of interest on loans in terms of wheat would diverge from the rate on other commodities and there would be no single equilibrium rate (Sraffa, 1932a: 49).

Sraffa illustrated his argument in terms of two economies, one with and the other without money, and exemplified the main idea with regard to a cotton trader:

The rate of interest which he pays, per hundred bales of cotton, is the number of bales that can be purchased with the following sum of money: the interest on the money required to buy spot 100 bales, plus the excess (or minus the deficiency) of the spot over the forward prices of the 100 bales (ibid: 50 ).

Let $i_{t, \theta}$ be the money rate of interest for $\theta$ periods, $p^{t}$ and $p^{t+\theta}$ the spot and the forward price of a bale of cotton, then the sum of money $M$ under consideration is

$$
M=\left(1+i_{t, \theta}\right) p^{t}-p^{t+\theta}
$$

The commodity rate of interest of cotton between $t$ and $t+\theta, \rho_{t, \theta}$, is then given by the amount of cotton that can be purchased by this sum of money at the given forward price, that is,

$$
\rho_{t, \theta}=\frac{M}{p^{t+\theta}}=\frac{\left(1+i_{t, \theta}\right) p^{t}-p^{t+\theta}}{p^{t+\theta}}=\frac{\left(1+i_{t, \theta}\right) p^{t}}{p^{t+\theta}}-1
$$

Sraffa then defined a long-period equilibrium and deviations from it in the following way:

In equilibrium the spot and forward price coincide, for cotton as for any other commodity; and all the "natural" or commodity rates are equal to one another, and to the money rate. But if, for any reason, the supply and the demand for a commodity are not in equilibrium (i.e. its market price exceeds or falls short of its cost of production), its spot and forward prices diverge, and the "natural" rate of interest on that commodity diverges from the "natural" rates on other commodities (ibid: 50 ).

Therefore, out of equilibrium there is not only one "natural rate", as Hayek had wrongly maintained, but there are many natural rates. Sraffa added that

under free competition, this divergence of rates is as essential to the effecting of the transition [to a new equilibrium] as is the divergence of prices from the costs of production; it is, in fact, another aspect of the same thing (ibid: 50; emphasis added)

Using the terminology of the classical economists from Adam Smith to David Ricardo, what we have here is the well-known problem of the so-called gravitation of "market prices" towards their normal or "natural" levels, which are determined by costs of production inclusive of a uniform competitive rate of profits on the capitals invested in the various sectors. (Sraffa had analyzed systems of such prices beginning in late 1927; see Kurz 2006 and Gehrke and Kurz 2006.) Sraffa illustrated the basic idea underlying this process of gravitation in the following way:

immediately some [commodities] will rise in price, and others will fall; the market will expect that, after a certain time, the supply of the former will increase, and the supply of the latter fall, and accordingly the forward price, for the date on which equilibrium is expected to be restored, will be below the spot price in the case of the former and above it in the case of the latter; in other words the rate of interest on the former will be higher than on the latter (ibid.).

Sraffa also put forward the following objections to Hayek's argument. First, Hayek had contended that as a consequence of the banking system's eventual abandonment of its "mistaken" interest rate policy the economy will return to its old equilibrium. This, Sraffa 
objected, can hardly be the case, because in the meantime the policy will have changed the distribution of national wealth and income and thus one of the data defining the equilibrium (the other two being preferences of agents and technical alternatives of production).

Secondly, Hayek's idea that "voluntary savings" can be strictly separated from "forced savings" caused by the reduction in the output of consumer goods consequent upon a lowering of the money rate of interest and the shifting of productive resources away from the consumption goods and to the investment goods industries, is naïve. With the redistribution of wealth and income the voluntary savings of those who benefitted (suffered) from the redistribution will increase (decrease) and thus blur the picture. Hayek, Sraffa concluded, had not argued correctly and his theory did not explain the facts it purported to explain.

Keynes had reason to be grateful to Sraffa: the latter's criticism of Hayek's theory had effectively countered the assault on his intellectual project launched by Lionel Robbins and his circle at the LSE and had allowed him to develop The General Theory undisturbed from any further interventions by the Austrian economist. In chapter 17 of The General Theory, "The Essential Properties of Interest and Money", Keynes wanted to pay tribute to Sraffa's achievement. However, he did not only thank his younger colleague, he rather adopted the concept of commodity rate of interest, re-defined it and placed his entire theory upon it by arguing that the "money own rate of interest" was determined by liquidity preference, which, at a given time and place, is a conventional datum and typically prevents the volume of investment to attain a level that equals full employment savings (cf. Keynes, CW, Vol. VII: 222-44). It was the assumed downward rigidity of the money rate of interest that was responsible, Keynes argued, for an insufficient investment demand and the corresponding unemployment.

As we can see from his library and his yet unpublished papers, Sraffa was not at all happy with what Keynes had done. He felt that Keynes had seriously misunderstood the concept of commodity rate of interest and had grossly misapprehended its analytical potential. The following section shows why. We proceed in two steps. In the first part we summarize Sraffa's annotations in chapter 17 of his working copy of The General Theory. In the second part we deal briefly with two short manuscript fragments that were found in Sraffa's working copy of the book after Sraffa had passed away in 1983. These objections have far reaching implications because in Sraffa's assessment the theory of liquidity preference "involves all the functions considered in the system: it is, in fact, Keynes's system!" (Sraffa Papers: 1100) ${ }^{1}$ (For the following, see also Kurz 1996 and 2010 and Ranchetti 2002.)

\section{SRAFFA'S CRITICISM OF KEYNES}

\section{Annotations in Sraffa's Copy of "The General Theory"}

The main objections put forward in Sraffa's annotations are the following. First, Keynes used two contradictory definitions of the concept of commodity rate, Sraffa's and a new one according to which the rate is made up of three characteristics of any durable asset that supposedly can all be translated into interest rate equivalents and then be added up. These are: (i) the "yield" of the asset $q$, (ii) its "carrying cost" $c$, and (iii) the "liquidity premium" $I$, that is: $q+c+I$ (see $C W$, Vol. VII: 226). As against this Sraffa insisted that the concept is only defined in terms of an expected change of the price of the asset - a difference between its spot and future price. Secondly, as regards Keynes's choice of money as standard of value, Sraffa drew the attention to an important implication that Keynes had overlooked: "The point is, that in the case of the rate of the article chosen as standard, the effect upon it of the expected depreciation is concealed" (ibid: 227; emphasis added). Thus, an expected fall in the value of money implies, for example, a high "money-rate of wheat interest", which, alas, Keynes did not take into account. Third, Keynes did not reason correctly and occasionally arrived at conclusions that are exactly the opposite of what results from a cogent argument. His contention that the money rate of interest cannot fall to a level compatible with full employment savings, because the elasticity of production of money is zero and its elasticity of substitution close to zero or zero, cannot be sustained. In Sraffa's view, the chapter was a mess.

\section{Two Manuscript Fragments}

In the two manuscript fragments, which confirm this assessment, Sraffa argues in particular: (1) Keynes's concept of liquidity is vague and ambiguous. (2) There

${ }^{1}$ See Sraffa's Papers kept in Trinity College, Cambridge UK, as they have been catalogued by Jonathan Smith, librarian. 
is no reason to presume that a higher liquidity is always a good thing for each and every agent. (3) Keynes puts forward different and contradictory concepts of the commodity rate of interest. (4) He erroneously admits Fisher's effect for all commodities except money.

With regard to the second element, Sraffa observes that the liquidity preference curve - the inverse relationship between holding cash and the rate of interest - is reminiscent of the usual marginal utility curve: "liquidity is always an advantage, though diminishing". Sraffa objects that while for some agents it may be the case in a particular situation, for others it may be quite otherwise. Banks, for example, must remain solvent and liquid, but they must also make profits. When their income consists almost exclusively of interest, they must, with a lower rate of interest, get less liquid in order to keep up their income. Therefore, Sraffa concludes, it is generally impossible to say that there is a definite relationship between the quantity of money and the rate of interest - there is no such thing as a definite liquidity preference curve.

Advantages associated with carrying an asset, Sraffa insists, have nothing to do with its commodity rate. People who borrow money or any other asset typically do this not in order to carry what is being borrowed until the expiration of the contract. They rather borrow money to buy with it other things. What is being borrowed is not what is being kept, but the standard in which the debt is fixed. Therefore, it is irrelevant whether a person pays in money or wheat and whether what is borrowed is durable or perishable. Sraffa is convinced "that K. [Keynes] has in the back of his mind two wrong notions, which have entirely misled him", namely, that only durables can be borrowed and that they are borrowed for the sake of keeping them, a view Sraffa had already disposed of in his controversy with Hayek.

There remains the fact that a large quantity of money (cash) and a low rate of interest often go together, which seems to give the curve some plausibility. Yet according to Sraffa the "causation is the other way round": It is a low rate of interest that is responsible for a large quantity of money, not a large quantity of money that causes a low rate of interest. Banks can fix the money rate of interest, but they cannot fix with sufficient precision the volume of money in the economy. Attention ought to focus on those who demand loans (investors) and not on those who provide them with liquid funds (banks and savers). Keynes's theory of liquidity preference with its emphasis on the supply of loans, Sraffa concludes, is similar to the old long-period theory of the supply of savings that is elastic with respect to the rate of interest carried over to a short-period framework. We may paraphrase this with Alfred Marshall: "We meet an old friend in a new dress."

The commodity rate of interest, Sraffa observes, is defined with respect to the forward price compared to the spot price of a commodity and nothing else. There are two ways in which the commodity rates of interest can become uniform again: either via changes in prices and/or via changes in quantities. Surprisingly, Keynes allows for both possibilities with regard to all commodities except money. To see this, contemplate the case in which people suddenly develop a large propensity to hoard money. This will depress the economy and sooner or later commodity prices will start to fall. This implies a rise in the value of money. An expected further increase in the value of money implies, however, a lower "own rate of money interest", using Keynes's peculiar concept. Sraffa concludes: "therefore the money rate will be lower than other rates and not higher". He observes that this is "Fisher's effect, which K. admits for all commodities except money"; the reference is to Irving Fisher (1907). Sraffa summarizes his criticism of Keynes as follows: "Thus in the $\mathrm{K}$. case, the result on rates of int[erest]. is opposite to K.'s conclusion."

In the central chapter 17 of The General Theory, Keynes did not reason correctly and ended up in a maze of contradictions. Liquidity preference theory "Keynes's system" - is logically incoherent. Its basic concept is but another expression of the marginal utility of hoarding, which is but a particular variant of marginal theory. Keynes who with one foot had managed to escape from "habitual modes of thought" with his other foot was still tightly tied to them.

\section{CONCLUDING REMARKS}

Sraffa was very critical of Hayek's explanation of business cycles and economic depressions, which had as its core the conventional view of the problem of the choice of technique: If the banking system fixes the money rate of interest at too low a level, that is below the "natural" or "equilibrium" rate, producers will try to embark on "more roundabout", that is, more capital intensive processes of production. In a fully employed economy this necessitates channelling productive resources from consumer goods industries to investment goods industries. Investors will bid up the 
prices of such resources and cause an inflationary tendency. The output of consumer goods will fall. However, since preferences of agents have not changed, the monetary demand for consumer goods has not changed, which means that in a second step also the prices of consumer goods will be bid up and the inflationary tendency will become stronger. With higher consumer goods prices profit margins in consumer goods industries will become larger. This provides an incentive to increase the output of consumer goods again, which in turn necessitates channelling productive resources back into consumer goods industries. This will reverse the tendency towards a lengthening of the Böhm-Bawerkian "average period of production" and result in prematurely abandoned investment projects. The misallocation of capital due to too low a money rate of interest becomes obvious and productive capacity of the economy shrinks. According to Hayek the problem was not a lack of effective demand, as Keynes had maintained, but a lack of effective supply. If banks in response to the inflationary pressure that has built up eventually decide to increase the money rate of interest again, the system, Hayek contended, will return to its old equilibrium position. The attempt to boost the economy by means of a policy of easy money is thus argued to be self-defeating: after a costly detour in which productive resources have been wasted the system gets back to where from it started.

Sraffa felt that Hayek's entire argument was difficult to sustain. Hayek's commandment that economic policy should re-establish the equality between the money rate of interest and the natural rate made no sense, because there was not only one such rate, but there were many: in the extreme there were as many as there are commodities. Monetary policy had impacted on the distribution of income and wealth, and by its very nature was bound to do so. But by affecting the distribution of endowments and a fortiori of incomes of agents, it was not clear which equilibrium monetary policy should head for, one with a high rate of return on capital and a low real wage rate or one with a low rate of return and a high real wage rate. Hayek's argument relied on Carl Menger's famous distinction between goods of lower and higher order, which Böhm-Bawerk had adopted in his theory. Goods of the first order are consumption goods, goods of the second order are goods needed in the production of consumption goods, goods of third order are goods needed in the production of goods of second order, and so on. In an input-output framework such a distinction makes little sense, because one and the same good (e.g. wheat) may be both a consumption good and a means of production (wheat used as seed). Sraffa was also clear by the early 1930s that a lower (higher) rate of interest does not necessarily lead to a higher (lower) capital intensity as the conventional doctrine of the choice of technique maintained, but this argument played no role in his 1932 papers dealing with Hayek. Apparently Sraffa felt that the objections put forward sufficed to show that Hayek's argument was not sustainable.

Sraffa's criticism had dealt a serious blow to Hayek's explanation of economic fluctuations and Keynes was very pleased with Sraffa's performance. Interestingly, in private correspondence Schumpeter congratulated Sraffa to his achievement. Schumpeter, too, thought that Hayek's approach was mistaken, but his main objection was that business cycles and crises can only be understood when the important role of innovations and of "creative destruction" are taken into account. To believe that the World Depression could be understood in terms of the conventional view of the static choice of technique problem is extremely naïve (see Kurz 2013). In more recent times Hayek's theory has been used again in attempts to explain what has been dubbed "the great recession" in the aftermath of the bursting of the financial bubble in 2007 . The theory is however not only difficult to sustain from a theoretical point of view, it is also difficult to reconcile with important empirical facts, in particular the fact that in recessions and depressions we generally do not observe an increase in employment in the consumer goods industries.

While Sraffa was critical of Hayek, he was not supportive of the use Keynes made of the concept of "commodity rate of interest" in The General Theory. He rather assessed Keynes's liquidity preference theory, which revolved around Keynes's re-definition of the concept, as misconceived. Sraffa also had doubts about the conventional view, which Keynes had adopted, that investment demand is inversely related to the money rate of interest. Hence, Keynes's focus of attention was misdirected. Empirically, as we experience right now, both criticisms were well taken. The money rate of interest has not been prevented from falling to even negative rates in real terms, but this fall did not induce investment activity and cause full employment again. Sraffa was convinced that Keynes was still, as Keynes' had famously put it, the victim of "habitual modes of thought and expression". 


\section{REFERENCES}

Fisher, Irving (1907). The Rate of Interest. New York: Macmillan.

Gehrke, Christian and Heinz D. Kurz (2006). "Sraffa on von Bortkiewicz: Reconstructing the Classical Theory of Value and Distribution." History of Political Economy 38(1): 91-149. http://dx.doi.org/10.1215/00182702-38-1-91

Hayek, Friedrich A. v. (1931a). "Reflections on the Pure Theory of Money of Mr. J. M. Keynes." Economica 11: 270-95. http://dx.doi.org/10.2307/2548035

Hayek, Friedrich A. v. (1931b). Prices and Production. London: Routledge and Kegan Paul.

Hayek, Friedrich A. v. (1932b). "Money and Capital: a Reply." Economic Journal 42: 237-249. http://dx.doi.org/10.2307/2223821

Keynes, John M. (1971-88). The Collected Writings of John Maynard Keynes, 30 vols, managing eds. A. Robinson and D. Moggridge. London: Macmillan. In the text referred to as $\mathrm{CW}$.

Kurz, Heinz D. (1996). "Sraffa und die Keynessche Theorie der Liquiditätspräferenz." Homo oeconomicus 13(3): 363-91.

Kurz, Heinz D. (2000). "The Hayek-Keynes-Sraffa Controversy Reconsidered." Pp. 257-301, in Critical Essays on Piero Sraffa's Legacy in Economics, edited by H.D. Kurz. Cambridge: Cambridge University Press. http://dx.doi.org/10.1017/CBO9781139166881.007

Kurz, Heinz D. (2006). "The Agents of Production Are the Commodities Themselves. On the Classical Theory of Production, Distribution and Value." Structural Change and Economic Dynamics 17: 1-26. http://dx.doi.org/10.1016/j.strueco.2005.04.001
Kurz, Heinz D. (2010). "Keynes, Sraffa, and the Latter's 'Secret Skepticism'." Pp. 184-220, in The Return to Keynes, edited by B. Bateman, T. Hirai and C. Marcuzzo. Cambridge, MA and London, UK: The Belknap Press of Harvard University Press.

Kurz, Heinz D. (2012). "Schumpeter's New Combinations. Revisiting His Theorie der wirtschaftlichen Entwicklung on the Occasion of its Centenary." Journal of Evolutionary Economics 22: 871-99. http://dx.doi.org/10.1007/s00191-012-0295-z

Kurz, Heinz D. and Neri Salvadori (1995). Theory of Production. A Long-period Analysis. Cambridge: Cambridge University Press. (Paperback edn 1997). http://dx.doi.org/10.1017/cbo9780511625770

Ranchetti, F. (2002), "On the Relationship between Sraffa and Keynes." Pp. 311-331, in Piero Sraffa's Political Economy. A Centenary Estimate, edited by T. Cozzi and R. Marchionatti. London and New York: Routledge.

Sraffa, Piero (1932a). "Dr. Hayek on Money and Capital." Economic Journal 42(1): 42-53. http://dx.doi.org/10.2307/2223735

Sraffa, Piero (1932b). "A Rejoinder." Economic Journal 42(2): 24951. http://dx.doi.org/10.2307/2223822

Sraffa, Piero (1960). Production of Commodities by Means of Commodities. Cambridge: Cambridge University Press.

Wicksell, Knut (1898). Geldzins und Güterpreise. Jena: Gustav Fischer.

DOI: http://dx.doi.org/10.6000/1929-7092.2015.04.19

(C) 2015 Heinz D. Kurz; Licensee Lifescience Global.

This is an open access article licensed under the terms of the Creative Commons Attribution Non-Commercial License (http://creativecommons.org/licenses/by-nc/3.0/) which permits unrestricted, non-commercial use, distribution and reproduction in any medium, provided the work is properly cited. 